\title{
CLASSICAL ELEMENTS AND WORD-FORMATION IN ACADEMIC DISCOURSE
}

\author{
IRINA KOROTKINA \\ Moscow School of Social and Economic Sciences \\ 82/2 Vernadsky prospect, Moscow, 119571, Russian Federation
}

\begin{abstract}
Despite the variety of disciplinary discourses, the global academic discourse in English preserves the uniform language of study and research, the lexical corpus of which contains structures composed of classical elements, morphemes of Latin and Greek origin. Understanding and mastering this international academic corpus is essential for all members of the academy, especially neophytes and international researchers. However, the information concerning classical combining forms and word-formation in dictionaries, reference books and academic English teaching materials is often insufficient, inaccurate or unsystematic. The paper analyses the state of affairs in the study of classical elements in academic discourse in English and offers an interdisciplinary approach to more effective comprehension of academic vocabulary. The approach draws from linguistics, discourse analysis, contrastive rhetoric (viewed as intercultural rhetoric) and the theory of common underlying proficiency of language acquisition, aimed at developing academic vocabularies simultaneously in both the native language and English. The approach has been tested in a variety of academic contexts and provides an efficient model for developing academic vocabulary by activating the prior, tacit knowledge of classical elements shared by participants of academic discourse across cultures.
\end{abstract}

Keywords: academic discourse, classical elements, English word-formation, academic vocabulary, English for academic purposes, intercultural rhetoric, common underlying proficiency

\section{INTRODUCTION}

Academic discourse is inseparable from the language of the academy, which is shared by all the members to interact and create knowledge. The language of global academic discourse is mainly written English, presented in specific forms of scholarly and academic texts, which individuals use to discuss problems, collaborate, educate neophytes, and exchange ideas. According to Ken Hyland (2011), "[d]iscourse is at the heart of the academic enterprise" (171), so mastering academic English is essential for students and researchers regardless of their native language or field of study.

As the language of global academic discourse, academic English has specific features, such as the ways of organizing information in texts, the use of complicated syntactic structures and academic vocabulary (Hyland 2000; Jordan 1997). One of the major characteristics of academic English is that it employs lexical structures composed of classical elements, affixes and roots of Latin and Greek origin, which English inherited from Latin along with the role of lingua franca of academic communication. Classical elements play a central role in disciplinary terminology and general academic 
vocabulary. Words like bronchoesophagostomy, synchrophasotron, asthenosphere or hemidemisemiquaver are difficult to spell or pronounce, but they are recognized by members of disciplinary communities, who use classical elements productively to create new terms. Latin adoptions with affixation, not common in spoken English, permeate written academic discourse (compare: no doubt - indubitably, foolish - preposterous, true - incontrovertible, last - perpetuate, etc.).

Although mastering academic English is crucial in the global world with intensive information exchange, members of the academic community whose native language is other than English face more challenges in coping with scholarly texts and tend to be discriminated in writing for study (Hyland 2000, 2006; Bhatia 2002; Bizzel 1999) and publication (Flowerdew 2008; Tardy 2004; Uzuner 2008). They are even more disadvantaged by language and cultural diversity if the social aspects of academic discourse are taken into account, for it does not only imply the knowledge of language conventions in education and research, but "constructs the social roles and relationships which create academics and students and which sustain the universities, the disciplines, and the creation of knowledge itself" (Hyland 2011: 171). Language difficulties may therefore affect researchers' and students' social statuses and worldviews (Bizzel 1999) and force them to express their ideas or share research results in a way which is not common in their own discourses but is expected in academic discourse in English (Olschtain \& Celce-Murcia 2001; Grabe and Kaplan 1996).

Still, it is necessary for academic discourse to maintain the common core language of the academy to support the creation of knowledge and interaction within the global academic community. It is therefore crucial for international members of the academy to master the lexical corpus of the language, which requires systematic study of classical elements, their functions and word-formation. To make the study systematic, an integrated approach is needed, which can draw from linguistic studies in word-formation (Kastovsky 1977; Bauer 2002; Adams 2013; Plag 2003), discourse analysis (Hyland 2011; Schiffrin, Tannen \& Hamilton 2001; Flowerdew 2002), contrastive, or intercultural rhetoric (Grabe and Kaplan 1996; Connor 2008), and English for academic purposes (Hyland 2000; Flowerdew 2002; Jordan 1997), the methodology of which is framed by the study of academic discourse (Olshtain, E. \& Celce-Murcia 2001; McCarthy \& Carter 1994; Hatch 1992).

In this paper, I will analyze the problems of the study of classical elements and word-formation in academic English, and offer an interdisciplinary approach to academic vocabulary acquisition by non-native speakers of English based on combining the methods of the above listed disciplines with the theory of common underlying proficiency and the dual iceberg model of language acquisition designed by James Cummins (Cummins 1996, 2000). The specific features of the common underlying proficiency concerning classical elements in both Russian and English presented in the model, are meant to provide researchers and students with an explicit set of linguistic and analytical skills, which will help them develop conceptual knowledge of classical elements in both languages and master the lexis of both the global and native academic discourse across disciplines. 


\section{WORD-FORMATION IN MODERN ENGLISH: A LINGUISTIC PERSPECTIVE}

Today, there is no one accepted doctrine or "theory of word-formation" (Bauer 2002; Adams, 2013). One reason for the neglect of word as a language unit was the development of synchronic descriptive linguistics (Saussure 1916; Bloomfield 1935), according to which language is studied internally as a system of elements defined in relation to one another. The formation of words being closely related to external, changing factors had little to do with the new methodology. Productivity, essential in word-formation, also did not match the synchronic approach. Harris (1951: 255) considered the productivity of word elements beyond the methods of descriptive linguistics "since that is a measure of the difference between our corpus and some future corpus of the language". The precedence of the study of morphemes over the study of words was further supported by the "Chomskyan revolution" in linguistics (Chomsky 1957), syntactic structures becoming more important than words, and morphemes more important in forming the meaning of a whole sentence.

As theoretical linguistics formed its epistemology, developing scientific methods of inquiry, word-formation remained an area of uncertainty for researchers mainly because words depend more on acceptability and occurrence rather than regularity or grammatical correctness. Nevertheless, non-occurrence of particular words is a weak argument to consider word-formation insignificant, and some researchers admit that "it is an obvious gap in transformational grammars not to have made provision for treating word-formation" (Pennanen, 1972: 293). Focused studies in word-formation exist, and although researchers in the field are eclectic in approaches and avoid discussing such essential theoretical features of word-formation as productivity, they seem to be seeking for unity in theory (Kastovsky 1977; Bauer 2002; Adams 2013; Plag 2003). As Bauer (2002) points out, "researchers seem to be showing a greater willingness to blend various theoretical viewpoints when dealing with [word-formation]: to blend synchrony and diachrony, morphology and phonology, syntax and semantics" (6).

Paradoxically, it is the complexity of study and relation with the external world that makes the field of word-formation so attractive for both linguists specializing in different areas of linguistic theory, and researchers in applied linguistics involved in matters of teaching languages, especially those for academic or specific purposes.

Elements from classical languages are a perpetual source for forming new terminology and lexis in academic and professional discourse. Having been the lingua franca of scientific and cultural communication for many centuries before English, Latin lost its predominance as a written and spoken language by the end of the $19^{\text {th }}$ century, but still permeates today's international academic discourse. Not only are Latin affixes productive and accepted by participants of academic discourse in English, but also Greek and Latin roots are actively used to form new words (Bauer 2002; Green 2015; Kastovsky 1977). To describe the formation of such words, the new term 'combining form' was coined in morphological and lexicological studies (Menzel \& DegaetanoOrtlieb 2017). These elements have their own lexical meaning, but are commonly used in combination with other elements (affixes or other roots) to form complex lexical structures. 
Although the term 'combining form' is still disputable (Bauer 2002; Adams 2013; Kastovsky 2009), the Oxford English Dictionary uses it to refer to such elements, attaching a hyphen on the appropriate side of the element (e.g. hydro-, graph, -log- or photo-). Unfortunately, English dictionaries do not always make distinctions between derivation and compounding. The same elements are often presented as separate units in combinations with different affixes (e.g. -graph, -grapher, -ography) or in different representations (e.g. historio- from Latin and historicofrom Greek). Sometimes elements with lexical meanings are listed as affixes (e.g. some in chromosome as a suffix) (Menzel \& Degaetano-Ortlieb 2017: 190-191). Provided these inconsistencies are overcome, the number of combining forms will be much shorter and therefore clearer and more comprehensive for academic discourse participants.

Theoretical issues in word-formation have more implications for academic discourse than it might seem. Although linguists and lexicographers still argue about the consistency of the term 'combining form' or other labels of the concept, as well as the difficulties in defining its borders (Ргжіж 2005; Kastovsky 2009), the overwhelming prevalence of classical combining forms in academic and disciplinary discourses is considered obvious in all modern studies of word-formation. As science and technology spread, more and more technical and specific dictionaries tend to define combining forms as separate units. Unless this process is systematized, different sources will apply different classifications and impede understanding. Ргжж(2005) suggests that a more consistent labeling of word elements in dictionaries will help overcome the problems of today's solutions which are "to a large extent inconsistent, unexplained and hence confusing for the user" (p. 313). Indeed, agreement on one comprehensive system of labeling can alleviate interactions among the participants of the global academic discourse and specific disciplinary discourses.

Dictionaries are not the only resources for the academic discourse community to obtain the information about classical elements. Proper labeling and definitions are equally relevant in English for academic purposes (EAP). As Menzel and Degaetano-Ortlieb (2017: 189) point out, "[m]orphological awareness, the skill to analyse internal structures of complex words and to understand morphological rules of the native languages, is a comprehension and language production skill that has to be acquired by language users along with other linguistic skills." Frameworks for EAP pedagogy are informed and supported by studies in both linguistics and discourse analysis (Flowerdew 2002: 1), so classical elements are expected to be presented in them explicitly because the purpose of EAP is to meet the needs of neophytes of the academy, international students and non-native scholars, for "the EAP community have consistently taken [academic discourse] to be a single and uniform entity, with a 'common core' across disciplines and often genres" (Bhatia 2002: 29).

Sadly, EAP resources do not always refer to classical elements, and may contain inconsistences. Most academic vocabulary books are aimed at self-study, with affixes and roots listed in reference materials and appendices (e.g. Campbell, 2007; 
McCarthy \& O'Dell, 2008; Nadler, 2004). Such resources do not give any systematic explanations and sometimes appear confusing. For instance, the list of prefixes, such as ex-, de-, in-, or pre-, may include lexemes, such as semi, quasi, pseudo, mono, kilo or neo, and even the abbreviation $e$ - for electronic (McCarthy \& O'Dell 2008: 128-131). In this logic, the combining form anthropo- should also be considered a prefix because it occurs in words anthropology, anthropomorphic, and anthropometric. As a result, the users get a much longer list of 'prefixes' than necessary and either do not understand what a prefix is (in case of speakers of analytic languages), or get puzzled (in case of speakers of synthetic languages with a high morpheme-per-word ratio, like Russian). The language of academic discourse presented in EAP books should be especially clear and explicit; simplifications and generalizations are possible, but never ambiguity or confusion.

Explicit and systematic books about classical elements and word-formation exist. Two most prominent ones were published by American classicists in the mid-1960s (Levine 1965; Ayers 1986). They addressed American students in higher education and were aimed at helping them cope with complicated academic discourse. Notably, these books are still very popular in the US academic community, which proves that the grapholect language of academic discourse in English, which is meant to be read and written, but "too elaborate to be spoken" (Bizzel 1999: 9-10) is difficult to acquire for native speakers of English. Another notable fact is the publication of books on classical elements and Latin affixation for schoolchildren (Draze 2005; Callela 2004), which is the result of the US educational policy aimed at preparing students for understanding complicated lexemes used in the language of academic discourse starting from primary school.

I believe that the reason is not only the developments in academic writing, in which US researchers have made the most prominent contribution, but also the increasing importance of classical elements in the information society. The language of academic discourse permeates the language of media, creating specific blended discourses (Cotter 2001; Egorova 2011; Sinelnikova 2017). Although the focus of this paper is narrower, I will give just one example to demonstrate the social function of classical elements in creating discourse communities on the Web: the designers of a site the mission of which is to consult businesses in competitive markets coined the word Provictus as the domain title. The appeal of this inexistent, but transparent word with pinpoint accuracy attracting the target audience arises from the Latin prefix pro- (forward), root vict (win, conquer) and ending -us. It will not however attract those whose cultural and academic background is poor. The example shows how "the text encodes values and ideologies that impact on and reflect the larger world" (Cotter 2001: 416).

\section{A CROSS-CULTURAL APPROACH TO ACADEMIC VOCABULARY ACQUISITION}

The specificity of the lexis used in the English academic discourse is difficult for both native and non-native participants. However, speakers of synthetic languages can benefit from the similarities in word-formation between their native language and Latin, thus having an advantage in acquiring academic vocabulary in English, of which native speakers seem to be deprived. 
Similarities and differences between written academic discourses of different languages are subject to contrastive rhetoric, which provides the basis for acquiring or producing discourse in a manner that is considered acceptable in the target language (Olschtain \& Celce-Murcia 2001: 716). Describing the study of contrastive rhetoric, Grabe and Kaplan (1996) define the rationale for this approach as meeting "preferred expectations about the way information should be organized" (109). As the global academic discourse involves cross-cultural interactions in educational and scientific contexts, contrastive rhetoric research agenda are gaining a momentum. To match the situation, Connor (2008) considers it more appropriate to change the name of the study into "intercultural rhetoric". I consider the term most relevant to describe the crosscultural conventions which emerge in the study of classical elements in English and Russian.

Indeed, the academic conventions in L1 (the native language) and L2 (the language of academic discourse, English) develop synchronously and influence social and cultural development of an individual as a member of the global academic community and the local, university or disciplinary community. Analyzing word-formation and combining elements in English, students refer to similar classical elements in L1 and decode their meanings; operating the elements as separate units, they can reconstruct the meanings of words in both languages, thus reconsidering academic discourse in their native tongue. For instance, in decoding the word dislocation, two Russian words occur: дислокаиия and размешение (the roots of the same meaning loc, мест). The root loc becomes clear in meaning, which along with Latin affixation becomes a key to decoding many English and Russian words alike: localize, collocation, allocation, relocate, delocalization, локализовать, локация, аллокация, коллокация, локальный, локатор, etc.

Parallel development of academic vocabularies in both academic languages (and therefore succeeding in both academic discourses) is best represented by the dual iceberg model of language acquisition designed by James Cummins (1996, 2000). The model resembles an iceberg with two tips rising above the surface with the common 'underwater' part. The two surface features represent L1 and L2, and the 'underwater' part is referred to as 'common underlying proficiency' (CUP) defined as "an underlying cognitive/academic proficiency that is common across languages" (Cummins 1996: 111). According to this notion, students can actively involve the knowledge and concepts obtained in L1 to support L2 acquisition and vice versa. The knowledge and concepts therefore form the common basis for both the acquired languages and are transferable from one language to the other. The development of either language contributes to the development of the CUP, and the whole iceberg grows. In case of academic vocabulary, the CUP is the corpus of classical elements obtained by individuals in their lives through culture and education, which provides the basis for boosting both vocabularies. In terms of discourse analysis, CUP is close in meaning to the term 'prior knowledge' (Olshtain, E. \& Celce-Murcia 2001; McCarthy \& Carter 1994; Hatch 1992), which refers to all tacit and explicit knowledge of an individual and plays a central role in reading and writing as a "conceptual framework for interacting with the world" (Olshtain, E. $\&$ Celce-Murcia 2001: 707). 
The CUP for classical elements in Russian and English academic discourse includes the following features:

1. Words of classical origin recognizable in both English and Russian and already familiar to students, e.g. evolution, construct, perspective, deductive, illusion, circulate, organize, reproduction, encyclopedia. Individuals may significantly differ in their cultural and academic backgrounds, but in a discourse-based model for language pedagogy these differences serve as a source for shared knowledge (Olshtain, E. \& Celce-Murcia 2001: 711). Shared vocabulary enhances interaction in a group which acts in educational context as a discourse community (Swales 1990: 24).

2. Words of classical origin and proper nouns which can be guessed despite the differences in spelling and affixation in Russian, e.g. apocalypse, euthanasia, mythology, orthography, eunuch, aegis, Phoenician, Thermopylae, Aphrodite. Most such words can be decoded provided the regularities of spelling Greek in English and Russian are revealed. For instance, the Russian Cyrillic tradition of spelling Greek words can be roughly divided into two periods, before Peter I, when words were taken directly from Greek, and after, when scientific terms started to come from Western Europe in Latin. Because of that we spell, for instance, the Greek beta and theta differently in older and later adoptions, e.g. mythology, orthography with ' $\phi$ ', but theory, orthodox with ' $m$ '; Babylon, Thebes with ' $\theta$ ' but bibliography with ' $\sigma$ '. As for ph, ch, $y$ (i-Greek), eu, oe or $a e$, correspondences are easily listed; for instance, oe and $a e$ typically occur as ' $\ni$ ', although this letter mainly occurs in the beginning of a word (e.g. aesthetics, aegis, Oedipus, but phoenix, archaeology). Words which appear in English without augments (e.g. aegis, Iris, Venus, pharaoh) can be guessed in context if the possible augment is expected; in Russian, augments occur in words like имя, мать, дочь, etc.

3. Words containing combining classical elements, the meanings of which can help decode unfamiliar words in both languages, e.g. the words gynecology, misanthrope, polyglot help decode misogyny and polygyny; Sophia and philosophy containing soph as "wisdom" is a key to sophisticated, sophistry, sophism, sophomore; hypothesis, monograph — hypograph; hypo-, geography — hypogaeum, subordinate, territory Subterranea, etc. Some words in Russian and Latin are similar (e.g. vert - вepm, turn; vid-вид, see; sem-ceм, seed; ос-ок/оч, eye; sid-cud, sit; $i-u / u d$, go), which helps decode words like subvert, disseminate, binoculars, president, transient. Thus, the word provision in "government provision" should be decoded as "seeing forward', instead of being misinterpreted by the Russian провизия ('food supplies').

4. Latin prefixes, the core of CUP of academic discourse. They have only grammatical meaning, and they are few; their list should consequently be as short as that of the English prepositions (postpositions), commonly used to explain Latin prefixes (e.g. destroy - pull down, compose - put together, repell - drive back, insert - fill in, etc.) or Russian prefixes. If not confused with Greek elements, like meta-, quasi- or peri-, or lexemes, like mini-, neo- or milli-, Latin and Russian prefixes match each other well (e.g. pro-pulse — про-талкивать, pre-dict — прред-сказывать, dis-miss рас-пускать, con-vention - со-брание, se-paration - от-деление). There are some problems with Russian irregularities, such as the polysemantic prefix nepe-, or no 
correspondence for de-; in such cases, English postpositions can be used (re- - back; thans- - across; per- - through; de- - down).

An essential characteristic of Latin prefixation is assimilation, which is regular in some prefixes (e.g. in-, con-, syn-: immobile, irrelevant, combine, correlation, colloquial, syllabus, sympathetic), and more complicated in others (e.g. sub-: support, surrender, succumb, sustain; ad-: acquire, account, allocate, associate, affiliate, aggregate). The knowledge of assimilation is an incredibly powerful tool of decoding the meanings of words in academic texts. Decoding familiar words is also a useful experience: e.g. as-soc-iate (ad-) as npu-общ-umb or sy-stem (syn-) as 'growing from the same root' (unlike com-position, 'putting together').

Unfortunately, Russian researchers do not only confuse prefixes with other elements, e.g. dys-, meta- (Zubenko, Masneva 2002: 89), bi-, multi-, semi-, micro-, vice-, mini-, milli- (Yanutik, Amatov 2017: 78-80), but define them in words; for instance, con- "совместность, соединение”, pre- “предварительно, предшествование во времени" (Yanutik, Amatov 2017: 78), although the Russian prefixes co- and пред- are clearly seen in the defining words.

This brief analysis shows that CUP is not a collection of mere concepts, but analytical skills and intellectual practices (higher-order thinking) which provide individuals with "conceptual framework for interacting with the world". Taking it into account, the CUP can be further supplemented with some more general, but systematic and therefore useful knowledge about the functioning of classical elements in academic English:

1. Classical elements are used in formal and metaphoric contexts (compare: fatherly - paternal, walker - pedestrian, understanding - comprehension, words lexis, look - regard, etc.). Motherly love is felt, therefore, whereas maternal duties are usually considered. In academic context, the use of 'common' English is often limited to prepositions and articles. In students' essays, words like a lot instead of multiple or numerous, think instead of consider, speak instead of discuss, or great instead of significant or considerable are commonly corrected in teaching academic writing.

2. Greek elements are commonly used in natural sciences and technology, philosophy and philology, whereas Latin is used in social sciences (probably because of the Roman contribution to law and order) and communication (because of the millennial use of Latin as lingua franca). For instance, both the Latin root aqua and the Greek hydro mean "water", but the word aquatic refers to social activities (e.g. sports), whereas hydraulic to technologies (e.g. mechanisms); similarly, the word contemporary (Latin, con- — "together", temp — "time") is used to describe social relations, whereas the word synchronous with similar meanings of both Greek elements, physical motion; multicoloured (Latin) is used in everyday communication, whereas polychromatic with similar meanings of both Greek elements, in optics. Consequently, Latin is more common in academic vocabulary (communicative purposes), whereas Greek prevails in terminology (scientific purposes).

3. Latin elements are usually combined with Latin, Greek with Greek, and English with English (e.g. semi-annual, circum-scription, in-appropriate (Latin); hemi-sphere, 
mono-graph, a-typical (Greek); half-witted, un-kind, under-go (English)). Occurrence matters, and some Latin words become homely English, attaching English prefixes (e.g. unfortunate, underestimate, overcritical), and vice versa, some Latin prefixes occur in 'common' English words (e.g. remake, discharge, precooked). This, however, does not imply that English is becoming more synthetic: the opposite example is the use of a prefix as a separate word: prepped (a passive form generalizing verbs with pre-).

4. Many Latin roots occur in two forms, which can be distinguished as imperfect and perfect (e.g. duce/duct, cede/cess, vince/vict, leg/lect). The former is used in words with hypothetical, abstract or intellectual meaning, whereas the latter with physical, formal or legal. Compare: evince, convince - evict, convict; deduce, induce - deduct, abduct. This feature seems rather uncertain from the point of view of linguistics, but it helps understand why producer, introducer or seducer are formed with duce, but conductor or abductor with duct.

The distinctions can help students and scholars infer the meanings of academic words or terms from their inner contexts. In reading, when a larger context is available, inference is even easier, but in this case, it is not the matter of guessing. In writing, the use of such words can help writers develop academic literacy and meet the requirements of academic English generically, enriching their writing and making it more acceptable for the members of the academic or professional discourse community.

The skills of deciphering, spelling, pronouncing or combining the classical elements needs practicing, which is best done through learning. Although EAP courses specifically aimed at developing vocabulary skills are rare, an approach involving the specific features of classical elements was used to design the course of Academic Vocabulary for Social Sciences for postgraduate students of the Moscow School of Social and Economic Sciences. In the course, the listed features serve as the basis for explicit teaching, and the students' CUP, which varies due to the variety of individual cultural backgrounds, as the basis for interactive learning. To foster interaction, PowerPoint visual aids are involved: words, affixes or prompting images appear on the screen; for instance, students are offered a task to 'translate' words from Latin into Greek with increasing difficulty (e.g. aquatic - hydraulic, contemporary - synchronous, consonant - symphonic, subscription - hypograph, Subterranea - hypogeum), and the animated words follow their guess. It is essential that the differences in meanings are discussed by the students (this is where emerging images are helpful). As affixation is the most powerful tool for deciphering meanings, prefixes and suffixes are learned separately, step by step, through a variety of activities, which involve analysis and synthesis. They are then used to form multiple derivatives (e.g. emit, permission, omit, commitment, emissary, mission, remission, etc.) and mastered in bigger context (sentences or texts). More elaborate exercises involve matching synonyms and antonyms, or analogies, such as "Mankind is to misanthropy as marriage is to misogamy); Theocracy is to religion as plutocracy is to (answer: wealth).

The approach proved effective in a variety of academic contexts and discourse groups, including seminars for academics and researchers and classes for undergraduate students. Discovering classical elements becomes not only a key to better reading and 
writing in English, but also to a more careful use of words in L1. Applied for nearly two decades, the approach emerged into a book (Korotkina 2016), which is widely used by Russian students and researchers in self-study and EAP professionals in teaching students. The approach was presented in a number of publications (e.g. Korotkina 2017).

However arguable the features of the approach could be from the point of view of linguists or discourse analysts, it does provide a flexible and practical model of academic vocabulary acquisition. The approach enables the members of academic community not only to develop "the skill to analyse internal structures of complex words" (Menzel and Degaetano-Ortlieb: 2017), but also obtain academic literacy through discovering 'regular features of academic English that are well defined and teachable' and employing intellectual activities of 'higher-order thinking — decoding, conceptualizing, inferring, inventing, and testing' (Scarcella 2003: 10). Russian researchers also admit that developing the language of science, finding appropriate equivalents, and understanding other languages can help comprehend one's native tongue better (Kolesnikova 2010: 132) and that "the analysis of unknown words by wordforming elements provides a rational way to learn to understand scientific text [...] in English without a dictionary" (Zubenko and Masneva 2002: 87).

The idea behind the dual iceberg model is that the more conceptual, lexical and practical knowledge of classical elements an individual develops, the higher the level of his or her academic literacy becomes in both L1 and L2. Consequently, the more academic vocabulary rises 'above the surface' in the individual's writing and speaking, the more accepted he or she becomes by the academic community. In other words, the more classical elements per page, the more academic the text is.

However, this simple idea cannot be supported by quantitative methods of corpus analysis. Both terminology and academic vocabulary include classical elements, but terminology can vary. Some disciplines, such as medical science or physics, employ Greek combining elements virtually in every term, while management or pedagogy often employ general English words. Thus, comparison between the disciplinary corpora based on the frequency of classical elements will be irrelevant. Despite a high ratio of classical elements in terminology, many studies, for instance, in medical science and law, contain case studies described in vernacular language. Contrarily, unlike 'soft' social science, sociology, for instance, operates a very specific, highly terminological language of professional discourse. Words of classical origin abound in literature on public policy analysis, but it also contains real life examples of policy implementation, which can affect the average figures.

Academic vocabulary being steady and interdisciplinary in nature, could provide a basis for judging texts on academic literacy. However, apart from the difficulties caused by distinctions between terms and academic words, it is the quality, not quantity of classical elements that matters. Repetitive, limited use of popular academic lexemes is difficult to compare with the variety and complexity of vocabulary employed by proficient academic writers. The elite register and variety of words distinguish scholarly papers from popular science or students' papers - provided the whole text is written without an effort visible for the reader. Mastering scholarly writing requires not only 
expanding the writer's active vocabulary, but understanding the meanings and functions of its elements. Lexical proficiency strengthens the author's authentic voice, and it is the voice that makes the participant of academic discourse heard clearly and distinctly.

\section{CONCLUSIONS}

Although academic discourses vary in different disciplines, genres and cultural contexts, the global academic community preserves a single unified language, which enables effective communication among the members of the academy across disciplines, genres and academic cultures and therefore is essential for all the members to master. The language of study and research is a specific form of English, which includes complicated lexical structures formed of classical elements and employs the principles of Latin word-formation.

Mastering academic vocabulary requires analytic linguistic skills, which can be developed by students and researchers, neophytes of the academy and speakers of languages other than English. To make these skills explicit and manageable, the academic community needs an interdisciplinary approach, which draws from linguistic theory and lexicography, discourse analysis and EAP pedagogy. The pedagogy underlying the approach is only briefly presented in the paper due to its focus and scope, but demonstrates the benefits of such learning.

The complex studies of classical elements and word formation may also contribute to better organization of information in dictionaries, reference books and EAP teaching materials, increasing their efficiency for the users.

These studies may also provide an insight on the matters of academic writing and literacy for the Russian academic community. One of the major limitations for developing academic Russian is the lack of clear distinctions in using words of classical and native origin, and carelessness in adopting words (e.g. adding the words менеджмент (management) and администрация (administration) to the native управление and руководство). Academic vocabulary is certainly not the only issue in discussing clarity and efficacy of academic language, or its genres (for which a more focused study is needed). Russian scholarly publications often tend to be wordy and inexplicit, terminologically overloaded or syntactically complicated. Closer attention to the English language of the global academic discourse in its many representations may foster the developments in Russian for academic purposes and academic writing as a discipline, which is the matter of increasing concern among Russian scholars, academics and publishers.

(C) Irina Korotkina, 2018

\section{REFERENCES}

Adams, Valerie (2013). An Introduction to Modern English Word-formation. London: Routledge: Taylor and Francis Group.

Ayers, Donald M. (1986). English Words from Latin and Greek elements. University of Arizona Press.

Bauer, Laurie (2002). English Word-formation. Cambridge Textbooks in Linguistics. Cambridge University Press. 
Bhatia Vijay K. (2002). A Generic View of Academic Discourse. Academic Discourse. John Flowerdew (ed.) 2002. 21-39.

Bizzel, Patricia (1999). Hybrid academic discourses: what, why, how. Composition Studies, 27 (2). $7-21$.

Bloomfield, Leonard (1935). Language. London: George Allen \& Unwin.

Campbell, Colin (2007). English for Academic Study: Vocabulary. Reading: Garnet.

Callella, Trisha (2004). The Learning Works: Prefixes and Suffixes, Grades 4-8: Teaching Vocabulary to Improve Reading Comprehension. Creative Teaching Press.

Chomsky, Naom (1957). Syntactic Structures. The Hague: Mouton.

Connor, Ulla (2008). Mapping multidimensional aspects of research. Contrastive rhetoric: reaching to intercultural rhetoric. Ulla Connor, Ed Nagelhout \& William V. Rozycky (eds.). John Benjamins Publishing Company, pp. 299-316.

Cotter, Colleen (2001). Discourse and Media. The Handbook of Discourse Analysis. Deborah Schiffrin, Deborah Tannen \& Heidi E. Hamilton (eds.), pp. 416- 436.

Cummins, James (1996). Negotiating identities: Education for empowerment in a diverse society. Los Angeles, CA: California Association for Bilingual Education.

Cummins, James (2000). Language, Power and Pedagogy: Bilingual Children in the Crossfire. Clevedon, England: Multilingual Matters.

Draze, Dianne (2005). Red Hot Root Words: Mastering Vocabulary With Prefixes, Suffixes And Root Words (Book 2). Prufrock Press.

Flowerdew John (ed.) (2002). Academic Discourse. Routledge: Taylor \& Francis Group.

Flowerdew, John (2008). Scholarly writers who use English as an additional language: What can Goffman's "Stigma” tell us? Journal of English for Academic Purposes, 7, 77-86.

Grabe, William and Kaplan, Robert B. (1996). Theory and Practice of Writing: An applied linguistic perspective. Harlow: Pearson Education.

Green, Tamara M. (2015). The Greek and Latin Roots of English. $5^{\text {th }}$ ed. Lanham: Rowman \& Littlefield.

Harris, Zellig S. (1951) Methods in Structural Linguistics. Chicago: University of Chicago Press.

Hatch, Evelyn (1992). Discourse and Language Education. Cambridge: Cambridge University Press.

Hyland, Ken (2000). Disciplinary Discourses: Social Interactions in Academic Writing. London, Longman.

Hyland, Ken (2006). Disciplinary differences: Language variation in academic discourses. Hyland, Ken \& Bondi, Marina (Eds.) Academic Discourse Across Disciplines. Frankfort: Peter Lang. pp. $17-45$.

Hyland, Ken (2011) Academic Discourse. Hyland, Ken \& Paltridge Brian (eds.) The Bloomsbury Companion to Discourse Analysis. Bloomsbury.

Jordan, Robert R. (1997). English for Academic Purposes: A guide and resource book for teachers. Cambridge: Cambridge University Press.

Kastovsky, Dieter (1977). Word-formation, or: at the crossroads of morphology, syntax, semantics and the lexicon. Folia Linguistica, 10. 1-33.

Kastovsky, Dieter (2009). Astronaut, astrology, astrophysics: About combining forms, classical compounds and affixoids. Selected Proceedings of the 2008 Symposium on New Approaches in English Historical Lexis (HEL-LEX), Lammi, Finland, 25-28 April 2008, 1-13. 
Korotkina, Irina B. (2016). Academic Vocabulary for Social Sciences. Moscow: HSE Publishing House.

Korotkina, Irina B. (2017). Expanding academic vocabulary through logical games. Problems of Contemporary Science and Practice. Tambov State Technical University. 66 (4), 173-180.

Levine, Harold (1965) Vocabulary for the College Bound Student. Amsco School Publications.

McCarthy, M. and Carter, R. (1994). Language as Discourse: Perspectives for Language Teaching. London: Longman.

McCarthy \& O’Dell (2008). Academic Vocabulary in Use. Cambridge, England: Cambridge University Press.

Menzel, K. \& Degaetano-Ortlieb, S. (2017). The diachronic development of combining forms in scientific writing. Lege Artis: Language yesterday, today, tomorrow. II (2). 185-234.

Olshtain, E. \& Celce-Murcia M. (2001). Discourse analysis and language teaching. The Handbook of Discourse Analysis. D.Schiffrin, D.Tannen \& H.Hamilton (eds.). Blackwell Publishers, 2001, pp. 707-724.

Pennanen, E.V. (1972). Current views of word-formation. Neuphilologische Mitteilungen. 73, 292308.

Plag, I. (2003). Word-formation in English. Cambridge: Cambridge University Press.

Prćić, T. (2005). Prefixes vs Initial Combining Forms in English: A Lexicographic Perspective. International Journal of Lexicography. 18 (3), 313-334.

Saussure, F. de (1916). Cours de linguistique générale (Course in General Linguistics). Paris.

Scarcella, R. (2003). Academic English: A Conceptual Framework. Technical Reports, University of California Linguistic Minority Research Institute, UC Berkeley. Retrieved from: http://escholarship.org/uc/item/6pd082d4. Accessed 9 January 2018.

Schiffrin D., Tannen D. \& Hamilton H. (eds.) (2001). The Handbook of Discourse Analysis. Blackwell Publishers.

Swales, J. M. (1990). Genre Analysis: English in Academic and Research Settings. Cambridge: Cambridge University Press.

Tardy, C. (2004). The role of English in scientific communication: lingua franca or Tyrannosaurus rex? Journal of English for Academic Purposes, 3, 247-269.

Uzuner, S. (2008). Multilingual scholars' participation in core/global academic communities: A literature review. Journal of English for Academic Purposes, 7, 250 - 263.

Warren, B. (1990). The importance of combining forms. Contemporary morphology. Dressler, W.U., Luschützky, H.C, Pfeiffer, O.E. et al. (eds.). Berlin: de Gruyter. 111-132.

Egorova, L.A. (2011) The problem of scientific hypermedia discourse perception. Russian Journal of Linguistics. 2. 5-10.

Kolesnikova, N. (2010). What is important to know about the language and style of academic texts. Vysshee obrazovaniye v Rossii [Higher Education in Russia]. Part 1. 3, 130-137.

Sinelnikova, L.N. (2017). Rhizome and discourse of intermediality. Russian Journal of Linguistics. 21 (4), 805-821.

Yanutik S.Y., Amatov A.M. (2017). Derivational potential in prefixes of Latin origin. Belgorod State University Scientific Bulletin. Humanities. 14 (263), 34. 76-83 (in Russ.)

Zubenko I.V., Masneva I.E. (2002). Morfemnoye slovoobrazovaniye v latinskom i angliyskom yazykah [Morphemic word-formation in Latin and English] Yazyk i Kul'tura [Language and Culture]. 2, 86-90. (In Russ.) 
Article history:

Received: 28 December 2017

Revised: 25 January 2018

Accepted: 27 February 2018

\title{
For citation:
}

Korotkina, Irina (2018). Classical Elements and Word-formation in Academic Discourse. Russian Journal of Linguistics, 22 (2), 389-403. doi: 10.22363/2312-9182-2018-22-2-389-403.

\section{Bionote:}

IRINA KOROTKINA is PhD, Head of the Interdisciplinary Department of English Moscow School of Social and Economic Sciences, Associate professor at the School of Public Policy, Russian Presidential Academy of National Economy and Public Administration. She is a Member of the National Society of English Teachers (NATE) and author of a number of teaching manuals, educational programs and more than 70 scientific publications in the field of English language teaching methodology, academic literacy, distance learning and the use of Information and communication technologies in the educational process. Contact information: e-mail: irina.korotkina@gmail.com

\section{ЭЛЕМЕНТЫ ЛАТИНСКО-ГРЕЧЕСКОГО СЛОВООБРАЗОВАНИЯ В АКАДЕМИЧЕСКОМ ДИСКУРСЕ}

\author{
И.Б. КОРОТКИНА \\ Московская высшая школа социальных и экономических наук \\ 119571, Москва, Россия, пр. Вернадского, д. 82/2
}

Несмотря на многообразие дисциплинарных дискурсов и различия в национальных научных традициях, глобальный академический дискурс использует английский язык как единый язык образования и науки. Однако специфику академического языка определяет активное словообразование на основе элементов из классических языков как в терминологии дисциплин, так и в междисциплинарном контексте. Понимание функциональных особенностей этой лексики необходимо каждому члену академического сообщества, как студентам, так и исследователям, в особенности тем, для кого английский язык не является родным. К сожалению, информация о латинско-греческом словообразовании в английском языке в словарях, реферативных источниках и учебной литературе не всегда достаточна, точна и систематизирована. В статье обсуждаются проблемы изучения классических элементов и словообразования в английском языке и предлагается междисциплинарный подход к их изучению на основе лингвистической теории, дискурсивного анализа, контрастивной (межкультурной) риторики и теории общей компетенции, лежащей в основе развития родного и изучаемого языка. Подход был апробирован в различных образовательных контекстах и может быть использован в качестве модели для расширения лексики глобального академического дискурса на основе активизации скрытого в родном языке знания латинско-греческих элементов носителями других языков.

Ключевые слова: академический дискурс, элементы классических языков, словообразование в английском языке, лексика академического дискурса, межкультурная риторика, теория общей компетенции 


\section{История статьи:}

Дата поступления в редакцию: 28 декабря 2017

Дата принятия к печати: 27 февраля 2018

\section{Для цитирования:}

Korotkina, Irina B. (2018). Classical Elements and Word-formation in Academic Discourse. Russian Journal of Linguistics, 22 (2), 389-403. doi: 10.22363/2312-9182-2018-22-2-389-403.

\section{Сведения об авторе:}

ИРИНА БОРИСОВНА КОРОТКИНА - кандидат педагогических наук, заведующая кафедрой английского языка Московской высшей школы социальных и экономических наук, является членом Национального общества преподавателей английского языка (NATE), Российской ассоциации глобальной коммуникации и Российского общества по изучению американской культуры (ОИКС). Автор свыше 70 научных и учебно-методических публикаций, в том числе пяти учебных пособий. Сфера научных интересов: академическое письмо, проблемы академической грамотности и языка науки, требования к публикациям в зарубежных научных журналах, академическая лексика и проблемы терминообразования, международные исследования в области новой грамотности (New Literacy Studies), английский для специальных и академических целей (EGAP/ESAP), онлайновое образование, интернационализация образования и науки. Контактная информаџия: e-mail: irina.korotkina@gmail.com 